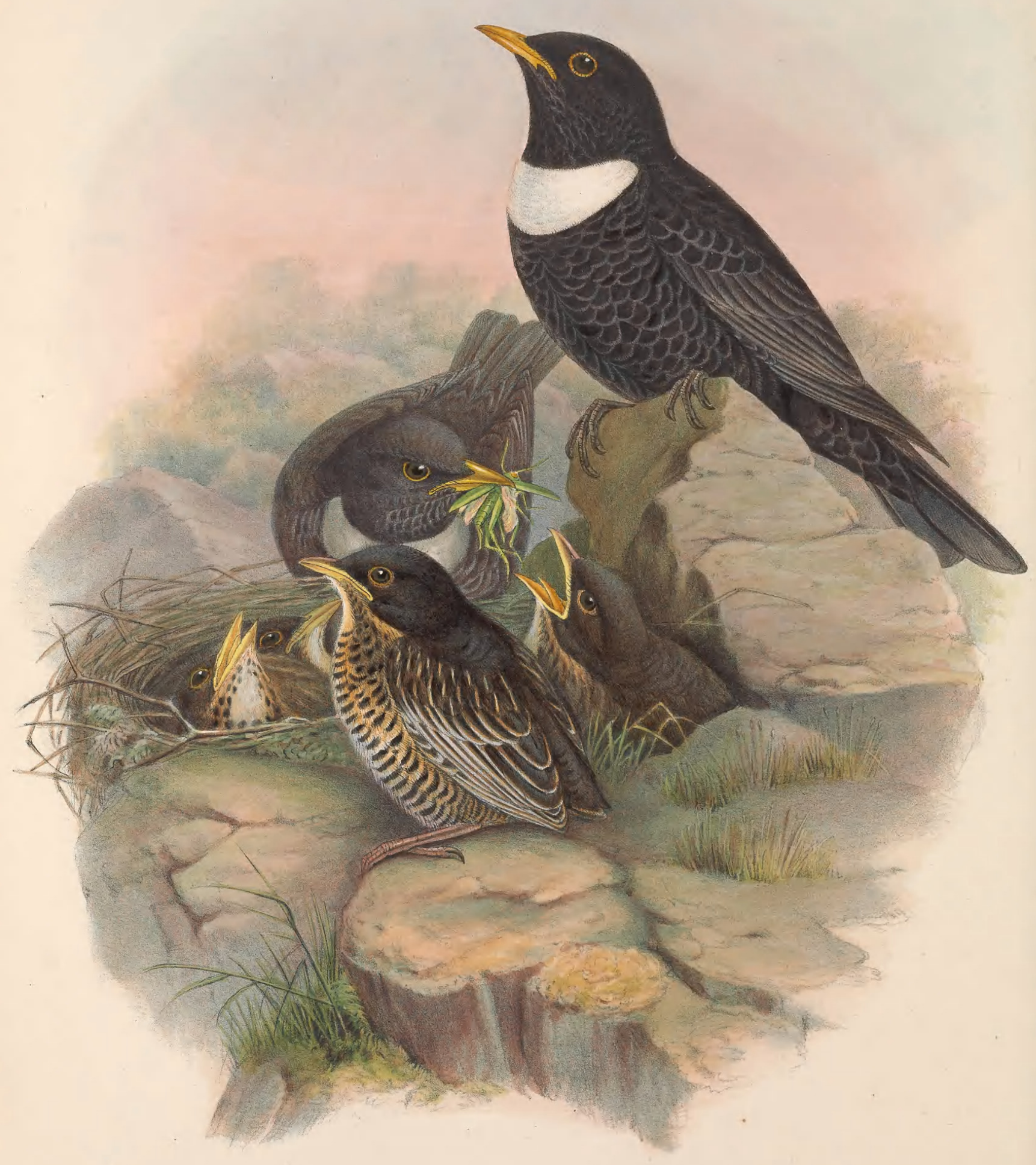




\section{MERULA TORQUATA.}

\section{Ring-Ousel.}

Turdus torquatus, Linn. Faun. Suec., p. 80

Merula torquata, Boie, Isis, 1822 , p. 552.

Sylvia torquata, Savi, Orn. Tosc., tom. i. p. 206.

Copsichus torquatus, Kaup, Natiirl. Syst., p. 157.

Merula montana, collaris et alpestris, Brehm, Vög. Deutschl., pp. 375, 376, 377, tab. 21. fig. 6 .

In the British Islands the Ring-Ousel must be regarded as a migratory bird; for it comes and goes as regularly as the Fieldfare and the Redwing,-but, unlike those birds, is a summer and not a winter sojourner, its arrival taking place in April, and its departure in the month of September. Its spring migration is very different from its autumnal movement; for it arrives singly or in small parties, and generally goes direct to its breeding-grounds on the hills ; while in autumn it is spread over the country, and we find both old and young in the lowlands, and sometimes in the gardens. They then gradually move southward, and before the cold weather sets in will all have departed to the western part of France, Portugal, and Spain, whence they again push onwards to the shores of the Mediterranean, and across that sea to their winter quarters in Morocco and other parts of North Africa.

Unlike the Blackbird, which locates itself in lowland woods, shrubberies, and gardens, the Ring-Ousel resorts to the wildest tracts of our mountains, and there, far from the haunts of man, it breeds, generally constructing its nest among the rocks of the wildest glens and the most rugged watercourses, but occasionally in juniper bushes or patches of furze on the mountain-side, high up on wild moors, tors, and peaks, where the drumming of the snipe is heard, the raven utters its sonorous croak, the Titlark and Wheatear are its companions, and the dashing Merlin its enemy. Generally speaking, wherever there are rocky mountains of above a thousand feet elevation, in any part of Britain, this spirited bird is to be found; so that the rugged parts of old Cornwall, the Dart- and Ex-moors of Devon, the greater part of Wales, Derbyshire, Cumberland, the Pentlands, the Grampians, and the bleak hills of Sutherland- and Ross-shires are among the places on the mainland frequented by it; while the islands to the north and westward-the Orkneys, Shetland, and the Hebrides-and all suitable situatious in Ireland, are not less resorted to.

Mr. Stevenson, speaking of the Ring-Ousel as seen in Norfolk, remarks that it is a regular migrant, but has been known occasionally to nest in that country; " and although probably overlooked from its general resemblance to the common Blackbird, and the similarity in the eggs of the two species, it is not improbable that a few pairs may breed nearly every year in favourable districts; and I have reason to believe that such is the case at Holkham."

Mr. Ryland, of Horsey, informed Mr. Stevenson that he generally saw several every year in the early spring, and in May 1857 watched four, morning after morning, on the grass in front of his window ; and as constantly did an old Missel-Thrush descend from an oak hard by, where she had a nest, and attack first one and then another, until she drove them away, showing that she would not permit of intruders, as these birds really were.

In disposition the Ring-Ousel is bold and spirited, perches with upright breast on the very summit of the rock, and springs from stone to stone with the greatest agility. At times, however, it is shy and recluse, but, when driven from the bush in which it has secreted itself, flies with surprising rapidity, uttering as it goes a loud defiant whistle, or, on again alighting on a stone or crag, its peculiar chattering notes, reminding us of the Petrocossyphi or Rock-Thrushes, to which, in my opinion, it is nearly allied.

It has always been an object with me while writing the present work to render as much general information as may be in my power respecting the range of the species over countries beyond our own. This in fact is essential; for every one, I should suppose, would like to know whither this bird, for example, goes when it leaves us, and whence it has come when it returns. The Ring-Ousel is by no means a cosmopolite; for it is not found in India, nor in Africa south of the equator, neither is it an inhabitant of America. In Europe, on the other hand, it is so generally dispersed that it may be said to frequent every country suited to its habits and economy. In the Alps and the Apenuines, as a matter of course, it is plentiful, as it is in the Tyrol in the east, and the highlands of Norway and Finland in the north, while in the low country of Holland it is a scarce bird. Southward of the Mediterranean, we learn from Loche that it winters in the provinces of Algeria and Coustantine. On the continent of Europe, as with us, it is a migrant-not that every one leaves a country or a district. To most rules there is an exception; and a Swallow or a Black-cap remaining with us does not constitute those birds permanent residents any the more. I have remarked that a considerable 
variation occurs between the Swiss birds and those of England, the Alpine birds being much lighter in colour, and having the little crescentic marks on the belly broader and more defined than those of the birds killed in this country. The pectoral mark varies very considerably in different individuals, being small and dusky in some, while it is large and snow-white in others; in the female, which is otherwise similarly clothed to the male, it is often suffused with brown, and in the young of the year is but faintly indicated. I am able to state this with certainty, after a careful examination of a number of specimens sent to me in the flesh by Sir John H. Crewe, Bart., who had them shot at different periods for the furtherance of this work. The figures of the young. birds in the accompanying Plate were drawn from examples obtained by myself in the Dovrefjeld, in Norway, where the bird was breeding in abundance at an elevation of 5000 feet. In the neighbourhood of Jerkin the young birds were just ready to leave the nest on the 1st of July; so that by September they would have become sufficiently strong to perform their southerly migration. The food of the Ring-Ousel, with us, consists mainly of insects and their larvæ; but, like the Thrush and Blackbird, it occasionally varies its diet with fruits and berries, among which the Whortle, the Bilberry, the Juniper, and the Mountain-Ash are included.

The Duke of Argyll tells me that in Argyllshire " the Ring-Ousel appears to be restricted in the breedingseason to an altitude above the sea which declines as you go north, like the snow-line. I never saw it here under an elevation of 1000 feet, except in autumn, when it comes down to eat the berries of several trees; but in Sutherlandshire I saw it along the wood-sides quite low down in spring."

Thirteen nests of the Ring-Ousel, from the late Mr. Heysham's collection, were all alike in form, and constructed of the same materials-namely, moss, roots, long grasses, and mud intermingled, which, when dry and hard, resembled the inside of a Thrush's nest; interiorly they have a warm lining of very fine grasses for the reception of the eggs. These nests are of large size, some of them considerably exceeding that of a Blackbird.

The eggs, which are from four to six in number, are regularly oval, and of a pale bluish green, freckled all over with pale brown, so much like those of the Blackbird as not readily to be distinguished with certainty.

All writers who have seen the "Mountain-Ousel" in a state of nature, speak highly of its vocal powers; and their remarks to a certain extent are truthful; for, besides a series of chattering notes which it freely utters on the approach of an intruder, its carol is pleasing and melodious, sweeter than that of a Thrush, but less spirited and vigorous, unlike that of its near ally the Blackbird, but somewhat resembling in quality the short but cheery song of Petrocossyphus cyaneus, the Merle bleu of the French, the "Sparrow on the housetop" of Scripture. "I was delighted with the song of the Ring-Ousel, which was to be heard through every clump of birch" (St. John, 'Tour in Sutherlandshire'). "Of all the Thrushes, perhaps the wild desultory carol of the Ring-Ousel is the loudest and clearest" (Wheelwright, 'Spring and Summer in Lapland'). "When alarmed, it utters a repetition of strong clear notes, like those of a Blackbird, but louder; and its song consists of a few simple loud and mellow notes" (Macgillivray, 'History of British Birds').

The adult male in the breeding-season has the bill yellow, clouded with dark marks on the upper mandible, and the naked lash which surrounds the eye pale olive-yellow; the tarsi and toes are reddish black.

The colouring of these parts of the female is similar, but more clouded than in the male.

The young, when they leave the nest, are without a trace of the white crescentic mark on the breast, have the under surface crossed with wavy lines of black and yellowish white, the inside of the mouth lemonyellow, and the legs and feet purplish brown.

The Plate represents the male, female, and young, of the natural size. 


\section{$2 \mathrm{BHL}$ Biodiversity Heritage Library}

Gould, John. 1873. "Ring-Ouzel, Merula torquata [PI. 38]." The birds of Great Britain 2, -. https://doi.org/10.5962/p.323852.

View This Item Online: https://www.biodiversitylibrary.org/item/221554

DOI: https://doi.org/10.5962/p.323852

Permalink: https://www.biodiversitylibrary.org/partpdf/323852

\section{Holding Institution}

Smithsonian Libraries

\section{Sponsored by}

Biodiversity Heritage Library

\section{Copyright \& Reuse}

Copyright Status: Public domain. The BHL considers that this work is no longer under copyright protection.

This document was created from content at the Biodiversity Heritage Library, the world's largest open access digital library for biodiversity literature and archives. Visit BHL at https://www.biodiversitylibrary.org. 